\title{
Image-Guided High-Dose Rate Intracavitary Brachytherapy in the Treatment of Medically Inoperable Early-Stage Endometrioid Type Endometrial Adenocarcinoma
}

\author{
Scott E. Jordan, MD \\ Temple Health Fox Chase Cancer Center \\ Ida Micaily, MD \\ Abington Jefferson Health \\ Enrique Hernandez, MD \\ Temple University \\ Follow this and additional works at: https://jdc.jefferson.edu/internalfp \\ 1 Stuart Ferriss, MD \\ S.iversity dafextarnal Medicine Commons \\ Let us know how access to this document benefits you \\ Curtis T. Milyamoto, MUD, FACR \\ Temple University \\ Recommended Citation \\ Jordan, MD, Scott E.: Micaily, MD, Ida; Hernandez, MD, Enrique; Ferriss, MD, J. Stuart; Miyamoto, \\ MD, FACR, Curtis T.; Li, PhD, Shidong; and Micaily, MD, Bizhan, "Image-Guided High-Dose Rate \\ Intracavitary Brachytherapy in the Treatment of Medically Inoperable Early-Stage Endometrioid \\ Type Endometrial Adenocarcinoma" (2017). Division of Internal Medicine Faculty Papers \& \\ Presentations. Paper 19. \\ https://jdc.jefferson.edu/internalfp/19
}

This Article is brought to you for free and open access by the Jefferson Digital Commons. The Jefferson Digital Commons is a service of Thomas Jefferson University's Center for Teaching and Learning (CTL). The Commons is a showcase for Jefferson books and journals, peer-reviewed scholarly publications, unique historical collections from the University archives, and teaching tools. The Jefferson Digital Commons allows researchers and interested readers anywhere in the world to learn about and keep up to date with Jefferson scholarship. This article has been accepted for inclusion in Division of Internal Medicine Faculty Papers \& Presentations by an authorized administrator of the Jefferson Digital Commons. For more information, please contact: JeffersonDigitalCommons@jefferson.edu. 


\section{Authors}

Scott E. Jordan, MD; Ida Micaily, MD; Enrique Hernandez, MD; J. Stuart Ferriss, MD; Curtis T. Miyamoto, MD, FACR; Shidong Li, PhD; and Bizhan Micaily, MD 
